\title{
DETERMINAN TIMELINESS PENETAPAN ANGGARAN PENDAPATAN DAN BELANJA DAERAH PEMERINTAH PROVINSI DI INDONESIA
}

\author{
Marissa Ramdhany ${ }^{1}$, Nurzi Sebrina ${ }^{2}$, Mayar Afriyenti ${ }^{3}$ \\ 1)Alumni Jurusan Akuntansi Fakultas Ekonomi Universitas Negeri Padang \\ ${ }^{2,3)}$ Jurusan Jurusan Akuntansi Fakultas Ekonomi Universitas Negeri Padang \\ *Korespondensi: tata.ramdhany94@gmail.com
}

\begin{abstract}
Timeliness of APBD is important in the management of provicianl finances. This research is aimed to examine the effect of government size, education background of executive, executive age, parliament size, parliament composition, liquidity, leverage, and auditor's opinion as the determinants to timeliness of APBD in Indonesia. The samples used in this study are all local goverments in the provincial level for the year of 2016. This study used a binary logistic regression model to test the hypothesis. The results show that the local educational background of executive, parliament size, and parliament composition do not have significant influences on the timeliness of APBD, but only parliament composition and audit opinion of Indonesia Supreme Audit Board (BPK RI) have significant influences on the timeliness of APBD.
\end{abstract}

Keyword: timeliness; educational background; age; parliament size; parliament composition; auditor's opinion

\section{How to cite (APA $6^{\text {th }}$ style)}

Ramadhany, M, Sebrina, N \& Afriyenti, M. (2019). Determinan Timeliness Penetapan Anggaran Pendapatan dan Belanja Daerah Pemerintah Provinsi di Indonesia. Jurnal Eksplorasi Akuntansi, 1(1) Seri D, 416-428.

\section{PENDAHULUAN}

Anggaran Pendapatan dan Belanja Daerah (APBD) merupakan rancangan keuangan tahunan pemerintah daerah yang dibahas dan disetujui bersama oleh Pemerintah Daerah dan Dewan Perwakilan Rakyat Daerah (DPRD) dan ditetapkan dengan peraturan daerah (Sutaryo, Sutopo, dan Wijaya, 2014). Proses penetapan APBD adalah proses politik dengan tahapan yang cukup rumit dan mengandung nuansa politik yang tinggi, dimana terjadi proses tawar-menawar antara eksekutif dan legislatif, serta merupakan pencerminan kekuatan relatif dari berbagai pihak yang terlibat dalam proses tersebut, yang masing-masing memiliki kepentingan berbeda terhadap APBD tersebut. Anggaran yang ditetapkan tersebut dipandang sebagai suatu kontrak kinerja antara legislatif dan eksekutif. 
Ketetapan waktu APBD adalah hal yang sangat penting karena jika penetapan APBD tidak dilakukan dalam waktu yang tepat, maka pada tahun anggran tidak akan terwujud pembangunan dan program kegiatan. Pada sebuah anggaran yang paling utama dilakukan adalah bagaimana cara menetapkan APBD sesuai peraturan Menteri Dalam Negeri Nomor 37 Tahun 2014 tentang pedoman penyusunan Anggaran Pendapatan dan Belanja Daerah tahun 2014 bahwa penetapan APBD 2014 paling lambat tanggal 31 Desember 2013.

Fenomena yang terjadi tahun belakangan ini pemerintah provinsi masih kurang mampu untuk memenuhi tanggal waktu yang telah diatur. Hal lain yang telah dikemukakan oleh (KPK, 2008) diIndonesia tahun 2005 dari 33 provinsi di Indonesia dimana terdapat 28 provinsi yang terlambat pengesahan APBD nya, sehingga provinsi yang mengesahkan APBD sesuai jadwal hanyalah 5 provinsi. Pada tahun 2009 juga terjadi keterlambatan pengesahan APBD di Indonesia, hal ini sangat disayangkan karena menggambarkan buruknya Pengelolaan Keuangan suatu Provinsi.

Batas waktu pengesahan APBD seharusnya dilakukan paling lama satu bulan sebelum tahun anggaran yang akan datang tiba. Hal ini harus doatuhi oleh kepala daerah, tetapi kenyataannya sangat banyak provinsi atau daerah yang melewati batas waktu tersebutt. Lambatnya dalam penyusunan anggaran suatu instansi pemerintahan dapat menimbulkan keterlambatan penyampaian data APBD. Kasus seperti ini meberikan kontribusi negatif sebab tenaga yang telibat dalam pembuatan proses APBD dikenakan sansi atas apa penyebab penundaan ini. Karena akibat dari tindakan ini daerah harus rela kehilangan dana insentiff daerah.

Faktor yang mengakibatkan lambatnya pengesahan APBD adalah hubungan antara ekskutif dan legislative yang kurang harmonis, kurangnya komitmen antara kepala daerah dan staff dan banyak lagi factor lainnya. Dalam perencanaan dan pembuatan APBD tidak lepas dari program yang telah ditentukan oleh pemerintah yang diberikan nama Rencana Kerja Pemerintah Daerah (RKPD) dalam rangka terwujudnya pelayanan kepada masyarakat demi tercapainya tujuan bernegara. Setidaknya mempunyai 6 (enam) subproses dalam penyusunan APBD yaitu: 1) Penyusunan Kebijakan Umum Anggaran Pendapatan dan Belanja Daerah, 2) Penyusunan Prioritas dan Plafon Anggaran Sementara, 3) Penyiapan Surat Edaran Kepala Daerah tentang Pedoman Penyusunan RKA SKPD, 4) Penyusunan Rencana Kerja dan Anggaran SKPD, 5) Penyiapan Rancangan Peraturan Daerah APBD dan 6) Evaluasi Rancangan Peraturan Daerah APBD.

Penelitian ini merupakan replika dari penelitian yang telah dilakukan oleh Verawati, dkk (2012) dimana aspek yang akan dibahas adalah umur kepala daerah, latar belakang, ukuran pemerintah daerah, ukuran DPRD dan opini audit. Data yang diambil dalam penelitian ini adalah da tahun 2016 sedangkan dalam penelitian Verawati dayang yang digunakan merupakan data tahun 2012. Ketetapan APBD pemerintah di Indonesia yang banyak dilakukan hanya berupa fator yang mempengaruhi penyususan APBD sedangkan penelitian ini akan melihat hubungan antara ketepatan waktu penetapan APBD dengan menggunakan lima faktor yaitu, umur kepala daerah, latar belakang, ukuran pemerintah daerah, ukuran DPRD dan opini audit.

Penelitian ini menggunakan Objek yaitu seluruh provinsi di Indonesia yang akan mengkaji lebih jauh tentang ketetapan waktu penetapan APBD. Dengan dilakukan penelitian yang dilakukan di Propinsi Indonesia harapan kedepannya dapat mengakses ketepatanwaktu pada website pemerintahan dalam penetapan APBD kepada pihak-pihak terkait. 
Dari pemaparan diatas serta penelitian yang dilakukan oleh peneliti terdahulu, maka peneliti mencoba mengangkat topik penelitian dengan judul "Determinan Timeliness Penetapan Anggaran Pendapatan dan Belanja Daerah Pemerintah Provinsi di Indonesia”

\section{REVIU LITERATUR DAN HIPOTESIS}

Menurut Zimmerman (1997), Pemerintah diartikan sebagai lembaga yang diberikan mandat pleh suatu kelompok, dalam hal ini adalah masyarakat untuk melaksanakan tugas pemerintahan yang tujuanny adalah untuk kesejahteraan rakyat. Dalam konteks lain, politisi sebagai wakil rakyat juga dapat disebut principal karena politisi harus menjalankan pengawasan yang telah dipercaya oleh rakyat.

Dalam konteks teori signalling, pemerintah berusaha untuk memberikan sinyal yang baik kepada rakyat (Evans dan Patton, 1987). Tujuannya adalah supaya pemerintah dapat berjalan dengan baik karena mendapatkan dukungan dari rakyat sehingga pemerintahan dapat berjalan dengan baik. Laporan keuangan menjadi sarana yang memberikan pertanggungjawaban kerja pemerintah kepada rakrat terhadap kinerja pemerintah. Kaporan keuangan juga berfungsi sebagai promosi untuk pihak eksternal.

Jika dikaitkan dengan penetapan APBD, pemerintah daerah atau eksekutif memutuskan ketepatan waktu APBD sesuai dengan kepentingan pelayanan publik. Peraturan Pemerintah Nomor 58 Tahun 2005 tentang pengelolaan keuangan daerah, selambat-lambatnya tanggal 31 Desember tahun anggaran sebelumnya. Pemerintah daerah akan menyusun anggaran daerah dalam bentuk Rancangan Anggaran Pendapatan dan Belanja (RAPBD), lalu DPRD akan memeriksa RAPBD yang diserahkan oleh pemerintah daerah. Dewan Perwakilan Rayat Daerah (DPRD) akan melakukan pengesahan RAPBD tersebut menjadi APBD, jika RAPBD yang diajukan telah dianggap sesuai dengan Rancangan Kerja Pemerintah Daerah (RKPD). Dewan Perwakilan Rayat Daerah (DPRD) akan memantau kinerja pemerintah daerah menggunakan APBD tersebut. Peraturan seperti ini adalah gambaran adanya kekompakan antara eksekutif dan legislatif. Oleh karena itu, penetapan APBD harus tepat waktu agar tercipta dan terwujudnya kepentingan publik. Apabila hak rakyat terpenuhi, maka rakyat akan sepenuhnya mendukung pemerintah, sehingga pemerintahan dapat berjalan dengan baik.

\section{Latar Belakang Kepala Daerah}

Kepala daerah merupakan orang yang pertama menentukan keadaan suatu daerah, latar belakang kepala daerah secara langsung membeikan kontribusi tentang cara bersikap dan berpikir. Bamber et al . (2010) menyatakan bahwa pemimpin yang berlatar belakang keuangan atau akuntansi berpotensi memiliki tingkat ketelitian yang lebih tinggi sehingga diharapkan dapat melakukan pengembangan kerja serta menciptakan kinerja yang lebih baik.

Dalam Peraturan Pemerintah Nomor 58 tahun 2005 tentang Pengelolaan Keuangan Daerah disebutkan bahwa kepala daerah merupakan Pemegang Kekuasaan Pengelolaan Keuangan Daerah (PKPKD) yang bertugas sebagai penyelenggara seluruh pengelolaan keuangan daerah. Pada dasarnya seorang kepala daerah dengan latar belakang pendidikan dibidang ekonomi, cepat dalam penetapan APBD, akan tetapi fenomena dilapangan masih terdapat kepala daerah yang berlatar belakang selain ekonomi. Hal ini berkontribusi negatif kepada hasil kerja kepala daerah tersebut seperti tidak bisa tepat waktu dalam penetapan APBD. 


\section{Umur Kepala Daerah}

Umur merupakan salah satu faktor penentu mengenai kebijakan kepala daeerah, karena umur (age) Kepala Daerah secara langsung sangat berpengaruh terhadap kemampuan atau ketelitian dalam membuat keputusan secara adil, percaya diri dan logis. Tua mudanya usia seseorang akan sangat berpengaruh terhadap kematanganya dalam berfikir dan mengambil keputusan. Pola dan cara berfikir yang baik dan matang dibutuhkan selama proses penyusunan anggaran sehingga terciptanya ketetapan waktu dalam penyusunan anggaran.

Kematangan umur seorang kepala daerah mencerminkan pemikiran yang matang pula, sehingga kepala daerah yangmempunyai umur yang matang dapat berfikir rasional, tidah ambigo dalam membuat anggaran sehingga tidak memerlukan waktu lama dan sangat disiplin terhadap waktu. Maka ketetapan waktu menetapan APBD dapat terrelisasi dengan baik.

\section{Ukuran DPRD}

Menurut Medina (2012), variabel yang digunakan dalam penelitian ketetapan waktu penetapan APBD adalah besar atau kecilnya suatu pemerintahan itu sendiri. Beberapa penelitian menyebutkan bahwa ukuran pemerintah daerah (size) berpengaruh positif terhadap ketepatan waktu penetapan APBD. Ukuran DPRD adalah jumlah anggota Dewan Perwakilan Rakray Daerah, dimana kita sama-sama mengetahui bahwa anggota DPRD merupakan wakil rakyat yang bertugas membela rakyat, memperjuangkan kepentingan rakyat dalam pemerintahan. Selain itu anggota DPRD juga bertugas anggaran pemerintah dapat dibuat tepat waktu dan emmastikan bahwa anggaran daerah tersebut dipergunakan untuk kepentingan rakyat.

\section{Komposisi DPRD}

Komposisi DPRD adalah penyebaran suara koalisi di DPRD dalam parlemen daerah dan dalam pemilihan kepala daerah, dimana politik di Indonesia menggunakan multi partai yang menyebabkan komposisi anggota DPRD terdiri dari banyak partai pula. Jika seorang kepala daerah didukung oleh koalisi yang pro rakyat maka akan mempunyai jumlah suara yang besar dalam pengambilan keputusan dalam DPRD. Contohnya adalah kualisi merah putih yang dipimpin oleh Prabowo Subianto yang memnangkan timp MPR pusat. Pada penelitian ini dapat disimpulkan timeliness dalam penetapan APBD terlihat ketidakkonsistenan hal ini mengakibatkan perlu dilakukan upaya engujian lebih lanjut untuk mengetahui konsistensi temuan jika diterapkan pada kondisi lingkungan yang berbeda.

\section{Auditor's Opinion}

Audit atas laporan keuangan bertujuan untuk menyatakan apakah laporan keuangan yang di audit tersebut disajikan secara wajar dan sesuai dengan prinsip akuntansi yang berlaku umum di Indonesia.Opini audit merupakan hasil dari laporan keuangan yang sudah diperiksa. Suatu laporan keuangan daerah yang mempunyai opini audit wajar tanpa pengecualian merupakan suatu prestasi bagi kepala daerah, dengan begitu masyarakat semakin yakin bahwa dana pemerintah dipergunakan dengan sebaik mungkin dan tanpa kecurangan.

\section{Hubungan Latar Belakang Kepala Daerah terhadap Ketepatan Waktu Penetapan APBD}

Latar Belakang Kepala daerah sangat berpengaruh terhadap ketepatanwaktu penetapan APBD karena kepala daerah merupakan orang yang pertama menentukan keadaan suatu daerah, latar belakang kepala daerah secara langsung membeikan kontribusi tentang cara bersikap dan 
berpikir. Bamber et al . (2010) menyatakan bahwa pemimpin yang berlatar belakang keuangan atau akuntansi berpotensi memiliki tingkat ketelitian yang lebih tinggi sehingga diharapkan dapat melakukan pengembangan kerja serta menciptakan kinerja yang lebih baik.

$\mathbf{H}_{1}$ : Latar belakang (background) kepala daerah berpengaruh positif terhadap timeliness atau ketepatanwaktu penetapan APBD.

\section{Hubungan usia kepala daerah terhadap ketepatanwaktu penetapan APBD}

Kematangan umur seorang kepala daerah mencerminkan pemikiran yang matang pula, sehingga kepala daerah yangmempunyai umur yang matang dapat berfikir rasional, tidah ambigo dalam membuat anggaran sehingga tidak memerlukan waktu lama dan sangat disiplin terhadap waktu. Maka ketetapan waktu menetapan APBD dapat terrelisasi dengan baik serta dengan mempunyai pemikiran yang matang kepala daerah bisa percaya diri dalam memimpin bawahannya untuk dapat bersama-sama menciptakan anggaran tepat pada waktunya.

$\mathbf{H}_{2}$ : Umur (age) kepala daerah berpengaruh positif terhadap timeliness atau ketepatanwaktu penetapan APBD.

\section{Hubungan Ukuran DPRD terhadap Ketepatanwaktu Penetapan APBD}

Anggota DPRD merupakan wakil rakyat yang bertugas membela rakyat, memperjuangkan kepentingan rakyat dalam pemerintahan. Selain itu anggota DPRD juga bertugas anggaran pemerintah dapat dibuat tepat waktu dan emmastikan bahwa anggaran daerah tersebut dipergunakan untuk kepentingan rakyat, dimana jika semakin banyak jumlah anggota DPRD maka pengawasan terhadap pembuatan anggran akan semakin kuat karena semakin terciptanya keragaman pikiran terhadap pembuatan anggaran. Maka terciptanya ketepatan waktu dalam penyusunan anggaran.

H3: Ukuran DPRD berpengaruh positif terhadap timeliness atau ketepatanwaktu penetapan APBD.

\section{Hubungan Komposisi DPRD terhadap Ketepatanwaktu Penetapan APBD}

Komposisi DPRD adalah penyebaran suara koalisi di DPRD dalam parlemen daerah dan dalam pemilihan kepala daerah, dimana politik di Indonesia menggunakan multi partai yang menyebabkan komposisi anggota DPRD terdiri dari banyak partai pula. Jika seorang kepala daerah didukung oleh koalisi yang pro rakyat maka akan mempunyai jumlah suara yang besar dalam pengambilan keputusan dalam DPRD sehingga anggaran dapat diselesaikan dengan tepat waktu.

H4: Komposisi DPRD berpengaruh positif terhadap timeliness atau ketepatanwaktu penetapan APBD

\section{Hubungan Opini Audit terhadap Ketepatanwaktu penetapan APBD}

Opini audit merupakan hasil dari laporan keuangan yang sudah diperiksa. Suatu laporan keuangan daerah yang mempunyai opini audit wajar tanpa pengecualian merupakan suatu prestasi bagi kepala daerah, dengan begitu masyarakat semakin yakin bahwa dana pemerintah dipergunakan dengan sebaik mungkin dan tanpa kecurangan. Semakin baik opini audit suatu daerah maka besar kemungkinan daerah tersebut melaporkan APBDnya dengan tepat waktu karena ketetapan waktu merupakan salah satu penilaian untuk menetapkan opini audit laporan keuangan suatu daerah. 
$\mathrm{H}_{5}$ : Opini Audit berpengaruh positif terhadap timeliness atau ketepatanwaktu penetapan APBD $\mathrm{H}_{6}$ : Latar belakang (background) kepala daerah, umur (age) kepala daerah, ukuran DPRD, komposisi DPRD dan opini audit berpengaruh positif secara bersama-sama terhadap timeliness atau ketepatanwaktu penetapan APBD

\section{METODE PENELITIAN}

\section{Jenis Penelitian}

Jenis penelitian ini tergolong penelitian kausatif dengan menggunakan pendekatan kuantitatif. Penelitian merupakan tipe penelitian untuk menganalisi pengaruh beberapa variabel dengan variabel lainnya.

\section{Populasi dan Sampel}

Populasi yang digunakan dalam penelitian ini adalah seluruh pemerintah provinsi di Indonesia yang tedapat pada website pada tahun 2016. Pemilihan sampel ditentukan dengan menggunakan metode purposive sampling. Purposive sampling dalam penentuan sampel dari populasi yang ada berdasarkan kriteria yang dikehendaki peneliti yang bertujuan untuk mendapatkan sampel yang sesuai dengan kriteria yang ditentukan.

\section{Jenis Data dan Sumber Data}

Jenis data dalam penelitian ini merupakan data dokumenter, data documenter meruapakan data yang di peroleh dari dokumen yang berhubungan dengan objek penelitian, data yang berhubungan dalam penelitian ini adalah nama provinsi di Indonesia dan daftar ketepatan waktu APBD pada tahun 2016. Sumber data dalam penelitian ini adalah data sekunder. Data sekunder merupakan sumber data penelitian yang di peroleh secara tidak langsung melalui media perantara, data ini umumnya berupa catatan, bukti, laporan historis yang telah tersusun.

\section{Teknik Pengumpulan Data}

Teknik pengumpulan data dalam penelitian ini yaitu dilakukan secara dokumentasi, dengan melihat nama-nama provinsi di Indonesia dan hasil penetapan Perda yang dipublikasikan oleh Perda APBD, Ditjen Bina Keuangan Daerah Kementrian Dalam Negeri, 2016. Untuk mrnfapatkan data sekunder dalam penelitian ini, penulis mengumpulkan dokumen, arsip dan data tertulis yang berhubungan dengan objek penelitian.

\section{Variabel Penelitian dan Pengukurannya}

\section{Variabel Dependen}

a. Latarbelakang kepala daerah

Latar belakang kepala daerah merupakan historis pendidikan maupun pekerjaan yang pernah dilampaui oleh seseorang. Sama-sama kita ketahui pada Undang-undang Republik Indonesia N0 20 tahun 2003 tentang sistem pendidikan nasional, tingkat pendidikan seseorang merupakan upaya yang mereka lakukan dalam mencapai proses pembelajaran supaya peserta didik secara aktif mengembangkan potensi dirinya untuk memiliki kekuatan spiritual keagamaan, akhlak mulia, kepribadian, kecerdasan, pengendalian diri serta keterampilan yang diperlukan dirinya, masyarakat, bangsa dan negara. Variabel ini diukur dengan cara : 
Skala ordinal diukur dengan menggunakan $1=$ jika kepala daerah berlatar belakang ekonomi akuntansi, $0=$ jika kepala daerah bukan berlatar belakang ekonomi akuntansi.

b. Usia kepala daerah

Variabel umur kepala daerah dihitung sesuai umur kepala daerah saat menjabat. Umur kepala daerah diukur berdasarkan jumlah umur usia atau usia kepala daerah ditetapkan sampai tahun 2016.

Rumus : Age $=$ ¿umur kepala daerah

c. Ukuran DPRD

Ukuran DPRD dihitung berdasarkan jumlah total anggota DPRD, penelitian ini menggunakan jumlah total anggota DPRD untuk mengukur ukuran DPRD.

Rumus: Size $D P R D=\sum$ anggota $D P R D$

\section{d. Komposisi DPRD}

Komposisi keanggota DPRD yang dominan dari partai pendukung eksekutif dan cenderung lebih cepat dalam pengambilan keputusan, salah satunya keputusan yang berkaitan dengan APBD. Tetapi jika komposisi DPRD lebih banyak diisi oleh anggota partai yang bukan dari partai pengusaha, dicemaskan akan terjadi konflik karena terciptanya perbedaan dalam pengambilan keputusan. Cara mengukur komposisi DPRD adalah dengan cara berikut:

$K O M P=$ Sanggota partai pendukung kepala daerah

e. Opini audit

Opini audit dapat diukur berdasarkan pendapat yang diberikan auditor yaitu : 1) Pernyataan tidak memberikan pendapat, 2) Opini tidak wajar, 3) Opini wajar dengan pengecualian, 4) Opini wajar tanpa pengecualian.

Rumus:

Skala ordinal diukur dengan menggunakan 1

jika WTP, 0 = jika selain WTP

\section{Teknik Analisis}

Untuk menguji hipotesis, penelitian ini menggunakan analisis binary logistic regression. Persamaan regresi yang digunakan dalam penelitian ini adalah:

TIME $=$ SIZE_PD + BACK + AGE +SIZE_DPRD +KOMP +CR + DER +AUD + e

TIME merupakan ketepatan waktu pemerintah daerah dalam melaporkan APBD, SIZE_PD adalah Ukuran Pemerintah Daerah, BACK melambangkan Latar Belakang Pendidikan Kepala Daerah, AGE merupakan Umur Kepala Daerah, SIZE_DPRD adalah Ukuran DPRD, KOMP adalah Komposisi DPRD, CR merupakan Current Ratio, DER adalah Debt to Equity Ratio, AUD adalah Pendapat Audit dan E melambangkan Error 


\section{HASIL DAN PEMBAHASAN \\ Hasil Penelitian}

a. Uji Normalitas

Dari hasil uji ini dapat disimpulkan bahwa data yang digunakan menunjukkan indikasi normal. Hal ini dilihat dari nilai asymp sig yang diperoleh yaitu 0.212 besar dari alpha 0,05, sehingga dapat dikatakan data bersditribusi normal.

b. Uji Multikolonieritas

Sesuai dengan ketentuan uji multikolinieritas, jika nilai VIF kurang dari 10 dan nilai tolerance besar dari 0,1 maka tidak terdapat korelasi. Berdasarkan hasil nilai VIF untuk ukuran pemerintah yaitu 1.217, latar belakang kepala daerah yaitu 1.080, Umur kepala daerah yaitu 1.162, ukuran DPRD yaitu 1.838, komposisi DPRD 1.781, liquidity yaitu 1.155, leverage yaitu 1.054 dan opini audit yaitu 1.110. Nilai VIF semua variabel bebas tersebut kurang dari 10. Nilai tolerance dari varibale bebas semuanya di atas 0.10. Sehingga dapat disimpulkan bahwa tidak terdapat multikolinieritas dalam data penelitian ini. Artinya bahwa antara variabel bebas tidak saling mengganggu.

c. Uji Autokorelasi

Di lihat dari uji ini diketahui nilai Durbin Watson yang dihasilkan dari model regresi adalah 1,767. Pengambilan keputusan pada asumsi ini memerlukan nilai bantu yang diperoleh dari tabel Durbin-Watson, yaitu nilai dL dan dU. Dengan $\mathrm{K}=8$ dan $\mathrm{n}=34$ maka: $\mathrm{dU}=2.069 \mathrm{dL}=0.954$ $-\mathrm{dU}=1.9314-\mathrm{d} \mathrm{L}=3.05$ Dengan demikian dapat disimpulkan bahwa $0.95<1.767<1.931$ artinya dalam model regresi ini tidak terdapat masalah autokorelasi karena memenuhi kriteria pengujian $\mathrm{dL}<\mathrm{DW}<4-\mathrm{dU}$.

d. Uji Heteroskedatisitas

Berdasarkan hasil analisis di atas gejala heteroskedastisitas ditunjukkan oleh koefisien regresi dari masing-masing variabel bebas terhadap nilai absolut residual. Jika nilai probabilitas lebih besar dari nilai Alpha atau (Sig > 0,05), maka dipastikan hasil uji di atas tidak terjadi gejala heteroskedastisitas. Berdasarkan data di atas di dapat nilai signifikan semua variabel bebas besar dari 0,05 sehingga disimpulkan tidak terjadi gejala heteroskedastisitas.

\section{Pembahasan}

Latar Belakang Kepala Daerah Berpengaruh Positif Terhadap Timeliness Penetapan APBD Provinsi Indonesia.

Hasil pengujian menunjukkan bahwa hipotesis kedua ditolak. Hasil pengujian latar belakang kepala daerah sebagai determinan timeliness penetapan APBD ternyata tidak terbukti karena memiliki nilai signifikansi 0,461 dimana nilai tersebut lebih besar dari 0,05. Hal ini berarti walaupun pemerintah daerah memiliki latar belakang pendidikan yang tinggi tetapi hal tersebut tidak dapat memepngaruhi penetapkan APBD dengan baik, karena latar belakang yang tinggi jika tidak didukung dengan tingkat pengalaman serta pengetahuan mengenai penyusunan anggaran maka hal tersebut tidak dapat mempengaruhi ketepatan dalam penetapan anggaran. 


\section{Umur Kepala Daerah Berpengaruh Positif Terhadap Timeliness Penetapan APBD Provinsi di Indonesia.}

Hasil pengujian menunjukkan bahwa hipotesis ketiga ditolak. Hasil pengujian umur kepala daerah sebagai determinan timeliness penetapan APBD ternyata tidak terbukti karena memiliki nilai signifikansi 0,892 dimana nilai tersebut lebih besar dari 0,05. Hal ini berarti bahwa umur kepala daerah belum mampu untuk mempengaruhi ketepatan waktu penetapan APBD, dengan kata lain dapat dikatakan bahwa kepala daerah yang berusia lebih matang jika tidak memiliki pengetahuan mengenai penyusunan anggaran maka ketepatan waktu penetapan APBD akan terlaksana dengan baik, sebaliknya kepala daerah yang memiliki usia muda tetapi memiliki pengetahuan mengenai penyusuan anggaran maka hal tersebut bisa saja dapat membuat waktu penyusunan anggaran sesuai dengan yang ditetapkan. Hal ini dapat dikatakan bahwa besar kecilnya usia kepala daerah tidak bisa menentukan ketepan waktu penetapan anggaran.

\section{Ukuran DPRD Berpengaruh Positif Terhadap Timeliness Penetapan APBD Provinsi di Indonesia.}

Setelah peneliti melakikan peneltiian dan menganalisa data menggunakan program SPSS maka mendapatkan hasil dalam pengujian hipotesis dengan hasil hipotesis keempat ditolak. Hasil pengujian menunjukkan bahwa ukuran DPRD tidak memiliki pengaruh signifikan terhadap timeliness penetapan APBD karena memiliki nilai signifikansi 0,213 dimana nilai tersebut lebih besar dari 0,05. Hal ini berarti bahwa jumlah anggota DPRD tidak dapat mempengaruhi timeliness penetapan APBD, karena besar atau kecilnya jumlah DPRD tidak dapat mempengaruhi ketepatan waktu penetapan APBD. DPRD yang berjumlah besar, penetapan APBD akan semakin kompleks karena melibatkan jumlah DPRD yang banyak, sementara DPRD yang bejumlah sedikit juga belum tentu dapat menjadi ukuran dalam ketepatan waktu penetapan APBD, karena jumlah DPRD yang sedikit bisa saja membuat DPRD tersebut lebih detail dalam menyeleksi anggaran, oleh karena itu jumlah DPRD tidak bisa menjadi suatu ukuran dalam ketepatan waktu penetapan APBD

\section{Komposisi DPRD berpengaruh positif terhadap timeliness penetapan APBD provinsi di Indonesia.}

Hasil pengujian menunjukkan bahwa hipotesis kelima diterima. Hasil pengujian menunjukkan bahwa komposisi DPRD memiliki pengaruh signifikan terhadap timeliness penetapan APBD karena memiliki nilai signifikansi 0,019 dimana nilai tersebut kecil dari 0,05. Hal ini berarti semakin besar komposisi partai pendukung kepala derah di DPRD maka hal dapat mempengaruhi ketepatan waktu penetapan APBD karena komposisi partai yang mendukung kepala daerah besar dapat memperlancar dalam penetapan APBD, dengan kata lain komposisi pendukung kepala daerah yang banyak di DPRD akan saling bersinerji dan bekerjasama dengan baik bersama kepala daerah dalam menyusun anggaran sehingga diperoleh ketapatan waktu dalam penetapan APBD, jika komposisi keanggotaan DPRD didominasi oleh anggota dari partai yang tidak mengusung kepala daerah, maka akan berpotensi mempunyai konflik yang lebih tinggi sehingga akan lebih lama dalam pengambilan keputusan APBD. Oleh karena itu semakn besar komposisi partai pendukung kepala daerah di DPRD maka akan dapat mempengaruhi kepada timeliness penetapan APBD. 


\section{Opini Audit Berpengaruh Positif Terhadap Timeliness Penetapan APBD Provinsi di Indonesia.}

Hasil pengujian menunjukkan bahwa hipotesis kedelapan diterima. Hasil pengujian menunjukkan bahwa opini audit memiliki pengaruh signifikan terhadap timeliness penetapan APBD karena memiliki nilai signifikansi 0,045 dimana nilai tersebut lebih kecil dari 0,05. Hal ini berarti opini audit dapat menggambarkan ketepatan waktu pemerintah dalam penetapan APBD karena opini yang dikeluarkan oleh audit atas laporan keuangan pemerintah daerah provinsi yang berupa opini non WTP (yaitu WDP, TW, atau TMP) dapat memacu pemerintah daerah untuk bekerja secara maksimal dalam menyusun anggaran sebaik mungkin dan tepat waktu, karena opini yang diberikan oleh audit mengambarkan kinerja dari pemerintah daerha, semakin baik kinerja dan penyusunan anggaran yang dilakukan maka semakin baik pula opini yang dibeirkan oleh audit, dan oleh sebab itu opini audit tersebut memberikan pengaruh terhadap ketepatan waktu penetapan APBD pemerintah provinsi. Hasil penelitian ini sejalan dengan penelitian Yusralaini (2010) yang mengungkapkan bahwa opini audit mempunyai pengaruh secara signifikan terhadap ketepatanwaktu penyampaian laporan keuangan.

\section{SIMPULAN DAN SARAN \\ Simpulan}

Berdasarkan hasil analisis dan pembahasan sebelumnya, berikut ini dapat disimpulkan beberapa hal antara lain Latar belakang kepala daerah pemerintah daerah tidak berpengaruh terhadap timeliness penetapan APBD. Hal ini berarti kepala daerah dengan latar belakan pendidikan yang tinggi sekalipun belum dapat untuk mempengaruhi ketepatan waktu penetapan APBD jika tidak memiliki pengetahuan mengenai penyusuan anggaran yang baik.

Umur kepala daerah tidak berpengaruh terhadap timeliness penetapan APBD. Hal ini berarti bahwa tingkat usia kepala daerah tidak bisa mempengaruhi ketepatan waktu penetapan APBD, karena kepala daerah yang memiliki usia matang sekalipun jika tidak memiliki kemampuan dalam penyusunan anggaran dengan baik maka usia yang dimilikinya tidak bisa membuat penetapan APBD tepat waktu.

Ukuran DPRD tidak berpengaruh terhadap timeliness penetapan APBD. Hal ini berarti dengan jumlah DPRD yang banyak atau sedikit tidak memberikan pengaruh terhadap timeliness penetapan APBD, jumlah anggota DPRD bisa membuat terjadinya ketimpangan pendapat sehingga terjadinya perselihan antar sesama anggota-anggota DPRD sehingga dalam penetapan APBD tidak sesuai pada waktu yang telah ditetapkan.

Komposisi DPRD berpengaruh terhadap timeliness penetapan APBD. Hal ini berarti semakin besar komposisi partai pendukung kepala daerah di DPRD maka keselarasan dalam penetapan APBD akan tercipta dengan baik, ketepatan waktu penetapan APBD akan tercipta.

Opini audit berpengaruh terhadap timeliness penetapan APBD.Hal ini berarti opini audit yang diberikan dapat memacu kepala daerah untuk bekerja secara maksimal dalam menyusun anggaran tepat waktu, karena opini audit merupakan predikat yang diberikan atas kinerja dalam penyusunan anggaran.

Latar belakang (background) kepala daerah, umur (age) kepala daerah, ukuran DPRD, komposisi DPRD dan opini audit berpengaruh positif secara bersama-sama terhadap timeliness atau ketepatanwaktu penetapan APBD. 


\section{Saran}

Berdasarkan hasil penelitian yang telah penulis uraikan sebelumnya, maka beberapa saran dapat dikemukakan yaitu disarankan kepada pemerintah daerah provinsi untuk menyusun anggaran tepat waktu karena hal tersebut merupakan kredibilitas dari pemerintah daerah dalam memberikan laporan mengenai APBD.

Disarankan kepada pemerintah daerah untuk memperhatikan varibale-variabel yang dapat mempengaruhi ketepatan waktu dalam penetapan APBD, dimana dalam penelitian ini adalah komposisi DPRD dan opini audit. Oleh sebab itu disarankan kepada pemerintah provinsi untuk menciptakan keselarasan dan hubungan kerja yang baik dengan DPRD begitu juga sebaliknya DPRD menciptakan keselarasan dan hubungan kerja yang baik sesama anggota serta dengan kepala daerah, karena dengan keharmonisan masing-masing pihak akan saling bekerjasama sebaik mungkin dalam penyusunan APBD sehingga bisa ditetapkan tepat waktu.

Kepada peneliti lainnya yang ingin meneliti mengenai timeliness untuk dapat menggunakan variabel independen lain diluar variabel penelitian yang telah dilakukan supaya lebih diketahui lagi variabel-variabel apa saja yang dapat memberikan pengaruh dalam ketepatan waktu penetapan APBD.

\section{DAFTAR PUSTAKA}

Abdullah, S dan Asmara, J. A. (2006). Perilaku Oportunistik Legislatif dalam Penganggaran Daerah: Bukti Empiris di sektor publik. Simposium Nasional Akuntansi IX. Padang apbdbatam2012-2014.blogspot.com/2015 diakses pada tanggal 8 Januari 2015.

Bamber, L. S., Jiang, J. \& Wang, I. Y. (2010). What's My Style? The Influence of Top Managers on Voluntary Corporate Financial Disclosure. The Accounting Review, 85(4).

Bastian, I. (2008). Akuntansi Sektor Publik Suatu Pengantar. Jakrta: Erlangga.

Cohen, S. (2006). Identifying The Moderator Factor of Financial Performance in Greek Municipalities. Financial Accountibility and Management, 24.

Departemen Pendidikan Nasional. (2008). Kamus Besar Bahasa Indonesia. Jakarta: Balai Pustaka.

Evans J., \& Patton J. (1987) Signalling nd Monitoring in Publik Sector Accounting. Journal of Accounting Research. 25, 130-158.

Fadzil, F. H. \& Nyoto, H. (2011). Fiscal Decentralization after Implementation of local Government Autonomy. Word Review of Business Research, 1(2), pp:51-70.

Forum Dosen Akuntansi Sektor Publik. (2006). Standar Akuntansi Pemerintahan: Telah Kritis PP No. 24 Tahun 2005. Yogyakarta: BPFE.

Ghozali, I. (2011). Analisis Multivariate dengan menggunakan SPSS 15.0. Semarang: Universitas Dipenegoro.

Halim, A. dan Abdullah, S. (2006). Penelitian tentang Hubungan dan Masalah Keagenan di Pemerintah Daerah (Sebuah Peluang Penelitian Anggaran dan Akuntansi). Jurnal Akuntansi Pemerintahan, 5(2)

Halim, A. dan Kusufi, M.S. (2013). Akuntansi Sektor Publik: Akuntansi Keuangan Daerah. Jakarta: Salemba Empat.

Herritaagustin.blogspot.com/2012/10/fungsiapbdhtmlhttps://eprints.uns.ac.id/2397/1/S43120802 5_pendahuluan 
Hilmi \& Ali. (2008). Analisis Faktor yang mempengaruhi Ketepatan waktu Penyampaian Laporan Keuangan (Studi Empiris pada Perusahaan-perusahaan yang terdaftar di BEJ Periode 2004-2006). SNA XI Surabaya.

Ibadin, Izilin, M., Izedonmi, F. \& Okoeguale, P. (2012). Association between selected Corporate Governance Attributes, Company Attributes and Accounting of Financial Reporting in Nigeria. Reseacrh Journal of Finance and Accounting, 3(9), 137-144.

Kartiko, W.S., Fitriany. dan Siregar. (2011). Pengaruh Opini Audit, Kualitas Auditor, dan Sistem Informasi Akuntansi terhadap Keterlambatan Penerbitan Laporan Hasil Pemeriksaan Laporan Keungan Pemerintah Daerah. Simposium Nasional Akuntansi 18 Universitas Sumatera Utara.

Mahmudi. (2011). Akuntansi Sektor Publik. Yogyakarta: UII Pres.

Mardiamo. (2002). Akuntansi Sektor Publik Yogyakarta: Andi Offset.

Medina dan Febri. (2012). Faktor yang mempengaruhi Transparasi Informasi Keuangan pada situs resmi Pemerintah Daerah Indonesia. Skripsi (Online). (http://lontar.ui.ac.id), diakses 30 Oktober 2014

Modugu, K. (2012). Determinants of Audit Delay in Nigerian Companies. Jounal of Finance nd Accounting, 3(6).

Nordiawan, D. dan Ayuningtyas, H. (2010). Akuntansi Sektor Publik. Jakarta: Salemba Empat.

Owusu-Ansah, S. (2000). Timeliness Corporate Financial Reporting in Stock Exchange. Journal Accounting and Business, 30(3).

Patrick, A. (2007). The Determinants of Organizational Innovativeness: The Adoption of GASB 34 in Pennsylvania Local Government. Thesis. Pennsylvania State University.

Peraturan Menteri Dalam Negeri RI Nomor 59 Tahun 2007 Tentang Perubahan Atas Peraturan Menteri Dalam Negeri RI Nomor 13 Tahun 2006 Tentang Pedoman Pengelolaan Keuangan Daerah.

Peraturan Pemerintah Dalam Negeri No 13 Tahun 2006 Tentang Pedoman Pengelolaan Keuangan Daerah.

Peraturan Pemerintah Dalam Negeri No 13 Tahun 2010 Tentang Standar Akuntansi Pemerintahan.

Peraturan Pemerintah No. 55 Tahun 2005 Pasal 1 Ayat 7 tentang Dana Perimbangan. Jakarta

Peraturan Pemerintah No. 58 Tahun 2005 Pasal 20 tentang Pengelolaan keuangan Daerah. Jakarta

Peraturan Pemerintah RI Nomor 71 Tahun 2010 Tentang Standar Akuntansi Pemerintahan.

Rachmawati, S. (2008). Pengaruh Faktor Internal dan Eksternal perusahaan terhadap Audit Delay and Timeliness. Jurnal Akuntansi dan Keuangan, 1(1), 1-10.

Rakyat Merdeka. (2012). Anggaran Pendapatan dan Belanja Daerah belum Disahkan Pemerintah Daerah. (0nline), (http://djkd.depdagri.go.id), diakses 15 Februari 2012

Simplenews05.blogspot.com/2014/08/proses-penyusunan-apbd.html.

Sinaga, Y. F. \& Prabowo. (2011). Analisis faktor-faktor yang mempengaruhi pelaporan keuangan di Internet secara sukarela oleh Pemerintah Daerah. Jurnal Universitas Diponegoro (Onlone). (http://eprints.undip.ac.id/, diakses 13 November2014).

Subechan, H. I. dan Haryono, S. B. (2014). Analsiis faktor penyebab Keterlambatan Penetapan APBD Kabupaten Kudus Wacana. 17(1).

Sugiyono. (2010). Metode Penelitian Kuantitatif, Kualitatif, dan R\&D. Bandung: Alfabeta. 
Sumarjo, H. (2010). Pengaruh karakteristik Pemda terhadap kinerja keuangan Pemda. Skripsi. Fakultas Ekonomi Universitas Sebelas Maret, Surakarta.

Supriyati \& Rolinda. (2007). Analisis faktor yang mempengaruhi audit delay (Study Empiris pada Perusahaan Manufaktur Financial di Indonesia). Jurnal ekonomi bisnis dan Akuntansi Ventura, 10(7), 109-126.

Sutaryo \& Carolina. (2014). Ketepatanwaktu Penetapan Anggaran Pendapatan Belanja Daerah di Indonesia. Simposium Nasional Akuntansi 17 Mataram, Lombok 27 September 2014.

Undang-Undang N0.17 Tahun 2003 Pasal 1 Ayat 8 tentang Keuangan Negara.

Undang-Undang No. 32 Tahun 2004 yang merupakan pengganti Undang-Undang N0. 22 Tahun 1999 adalah undang-undang yang mengatur tentang pemberlakuan otonomi daerah di Indonesia.

Undang-Undang Nomor 32 Tahun 2004 tentang Pemerintah Daerah dan Undang-Undang Nomor 33 Tahun 2004 tentang Perimbangan Keuangan antara Pemerintah Pusat dan Pemerintah Daerah. Jakarta

Undang-Undang Republik Indonesia No. 33 Tahun 2004 tentang Perimbangan Keuangan Republik Indonesia.

Verawati, J. A. K. dan Megawati. (2012). Determinan Timeliness Penetapan APBD Pemerintah Provinsi di Indonesia. SNA $X$.

Wahyono, T. (2004). Sistem Informasi Akuntansi: Analisis Desain dan Pemograman Komputer. Yogyakarta: Andi Offset

Yendrawati \& Rokhman. (2007). Faktor yang mempengaruhi Audit Delay pada Perusahaan Go Public di BEJ. Jurnal Keuangan dan Perbankan, 12(1), 66-75.

Yusralaini, A, R. \& Raesya, L. D. (2010). Analisis Faktor yang mempengaruhi Ketepatan Waktu penyampaian Laporan Keuangan ke Publik pada Perusahaan yang terdaftar di BEI 2005-2007. Jurnal Ekonomi, 18(2). 